\title{
Sideritic-kaolinitic and green clay layers in the Mecsek Mountains (SW Hungary): Indicators of Middle Triassic volcanism-Myth or reality?
}

\author{
Georgina Lukoczki ${ }^{1,2,3^{*}}$, Tamás Budai ${ }^{2,4}$, Tibor Németh ${ }^{5,6}$ \\ ${ }^{1}$ Boone Pickens School of Geology, Oklahoma State University, Stillwater, USA \\ ${ }^{2}$ Department of Geology and Meteorology, University of Pécs, Pécs, Hungary \\ ${ }^{3}$ Environmental Analytical and Geoanalytical Research Group, Szentágothai Research Centre, \\ University of Pécs, Pécs, Hungary \\ ${ }^{4}$ Geological and Geophysical Institute of Hungary, Budapest, Hungary \\ ${ }^{5}$ Institute for Geological and Geochemical Research, Research Centre for Astronomy and Earth \\ Sciences, Hungarian Academy of Sciences, Budapest, Hungary \\ ${ }^{6}$ Department of Mineralogy, Eötvös Loránd University, Budapest, Hungary
}

Received: January 31, 2016; accepted: February 1, 2016

Sideritic-kaolinitic and green clay layers were previously reported from the Mecsek Mountains (SW Hungary) as indicators of Tethyan volcanism in the otherwise germanotype Middle Triassic succession. The aim of the present study is to provide a review and a critical re-evaluation of the previously published data on both the sideritic-kaolinitic layers (the so-called "Mánfa Siderite") and the green clay layers. New results of mineralogical investigation of the green clay layers are also presented. The Middle Triassic volcanic origin of the "Mánfa Siderite" cannot be confirmed. In addition to a possible volcanic contribution, the sideritic-kaolinitic layers were probably formed in a freshwater swamp under humid, tropical climatic conditions, whereby weathering in an organic-rich, acidic environment led to the formation of "underclays" and siderite in the coal-bearing formations of Late Triassic to Early Jurassic age. These layers were probably tectonically placed over Middle Triassic carbonates. The illitic green clay layers intercalated in the Middle Triassic dolostone may represent terrigenous deposits, and the illite mineralogy probably is the result of burial diagenesis of detrital clays.

Keywords: Middle Triassic, siderite, green clay, swamp, tectonics, diagenesis

*Corresponding author: Georgina Lukoczki; Noble Research Center, Stillwater OK, 74078, USA

E-mail: gina.lukoczki@okstate.edu 


\section{Introduction}

During the mapping program of the 1960s numerous new boreholes and trenches helped assess the mineral resources in Hungary. The most important results were mainly published in Hungarian journals, including results about the green clay layers intercalated in Middle Triassic dolostone in the Western Mecsek Mountains and the sideritic-kaolinitic beds ("Mánfa Siderite") found in the Central Mecsek Mountains. In both cases volcanic origin and a Middle Triassic age of these formations were inferred (Wéber 1965, 1978; Nagy and Ravasz-Baranyai 1968); however, these interpretations were not supported by unequivocal analytical results. Despite this, these green clay layers and sideritic-kaolinitic beds have been known in the Mecsek Mountains as indicators of Middle Triassic volcanism.

Bleahu et al. (1994) were the first to mention an alternative origin for the Middle Triassic "argillaceous ironstones [...] consisting of kaolinites and siderites" considering them to be swamp deposits. The paludal origin for the "Mánfa Siderite" was also mentioned by Konrád (1998) and Haas et al. (2002) without any reference, original data or any new aspects of interpretation. Hervai (2006) investigated three clay samples collected from two locations in the Central Mecsek Mountains, which he identified as layers of the "Mánfa Siderite".

Recently, Konrád and Budai (2009) re-analyzed a green clay sample near Gorica taken from the same location first documented by Wéber (1965). Based on the mineralogical composition of one green clay sample Konrád and Budai (2009) refuted the volcanic origin and proposed a clastic one instead.

Understanding the paleogeography of the Mecsek Mountains is not possible without clarifying whether the formation of the above-mentioned deposits were indeed related to volcanism during Middle Triassic times. Thus, an attempt was made to unravel the myth surrounding these formations using modern analytical methods. However, our effort failed to find any residual material of the "Mánfa Siderite". Therefore, the aim of the present study remains to present a detailed description of these formations based on published resources, to present the results of basic mineralogical analysis of the green clays, a discussion of alternative origins of the clays, and to make inferences about the paleoenvironmental conditions, which prevailed during the deposition of both the "Mánfa Siderite" and the green clays.

\section{Paleogeographic and paleotectonic setting}

The study area is located in the Mecsek Mountains, SW Hungary, comprising a part of the Tisza Mega-Unit (Bleahu et al. 1994) (Fig. 1). During the Middle-Late Triassic the investigated area was located on the north-western shelf of the Tethys, around the $30^{\circ} \mathrm{N}$ latitude, and was dominated by sub-tropical trade winds (Szulc 2000; Török 2000; Götz et al. 2003; Feist-Burkhardt et al. 2008) (Fig. 2). This paleogeographic setting resulted in a semi-arid to semi-humid climate during the Late 


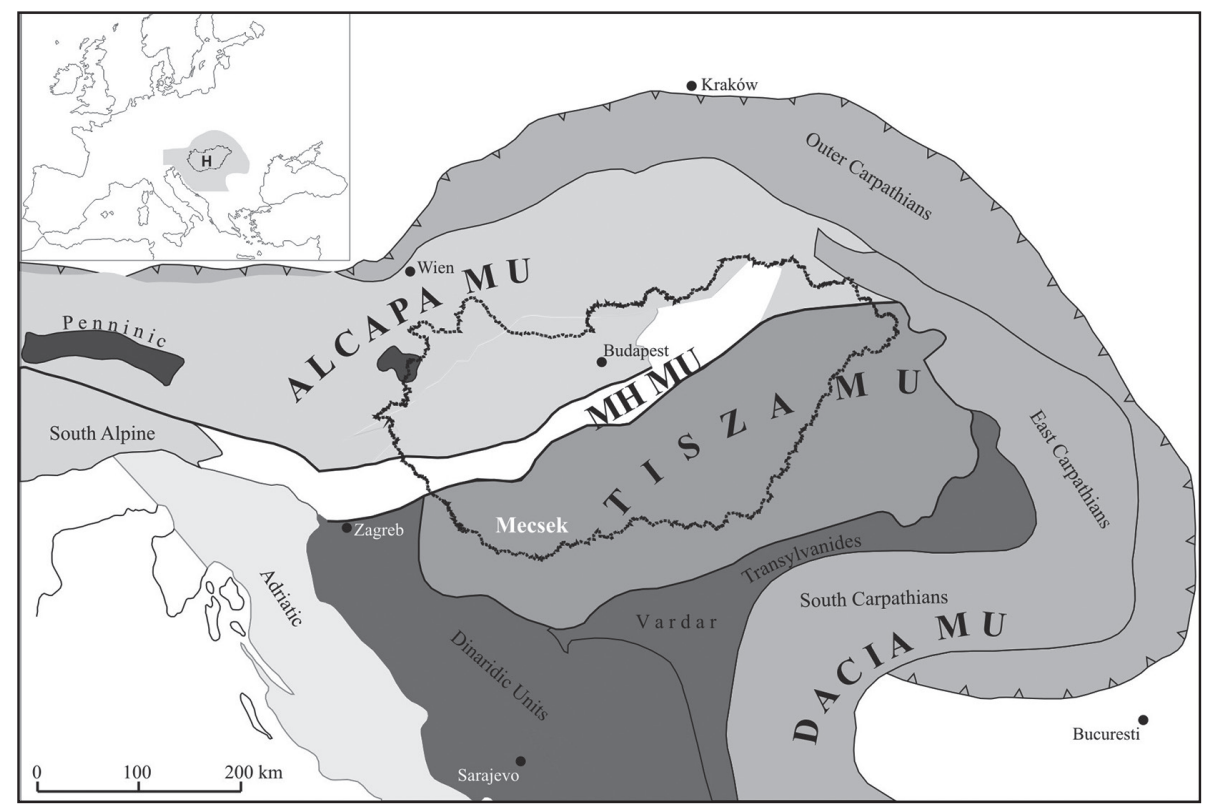

Fig. 1

Tectonic position of the Tisza Mega-Unit in the Alpine-Carpathian-Dinaridic system (simplified after Haas et al. 2010a). Abbreviations: MH MU = Mid-Hungarian Mega-Unit, MU = Mega-Unit

Anisian-Early Ladinian, and in a mostly arid to semi-arid climate during the Carnian-Rhaetian, with humid periods in the late Early Carnian and in the Rhaetian (Török 1993; Viczián 1995; Haas et al. 2012).

Sedimentological and paleontological features of the Triassic formations of the Mecsek Mountains show both Alpine and Germanic affinity. Alpine characteristics of the Mecsek Mountains were described in the earliest geologic literature (Beudant 1822; Peters 1862; Böckh 1881), while in the mid-1900s the Germanic facies affinity was emphasized (e.g. Vadász 1935; Wéber 1965, 1978; Nagy 1968). Nagy (1968) suggested that the area of the Mecsek Mountains had a transitional paleogeographic position between the Germanic and Alpine facies areas. Géczy (1973) was the first to interpret the different ammonite assemblages of the Hungarian Mesozoic successions with Alpine and Germanic facies affinity in terms of plate tectonics: he recognized that the areas with Germanic facies affinity (e.g. the Mecsek Mountains) originally comprised part of the northern margin of the Tethys, whereas areas with Alpine facies affinity (e.g. the Transdanubian Range) belonged to the southern margin, and their current inverse position is a result of subsequent horizontal displacement. Later, Kozur and Mock (1987) highlighted some contradictions regarding the Germanic affinity of the Mecsek Mountains. Nevertheless, modern sedimentological investigation by Török $(1993,1998)$ resulted in a detailed correlation of the Triassic sediments 
of the Mecsek Mountains with the Peri-Tethyan epicontinental sequences (Germany, Poland). According to his interpretation, the Triassic sediments of the Mecsek area were deposited on a "largely homoclinal" ramp with localized slumps suggesting distal steepening (Török 1993).

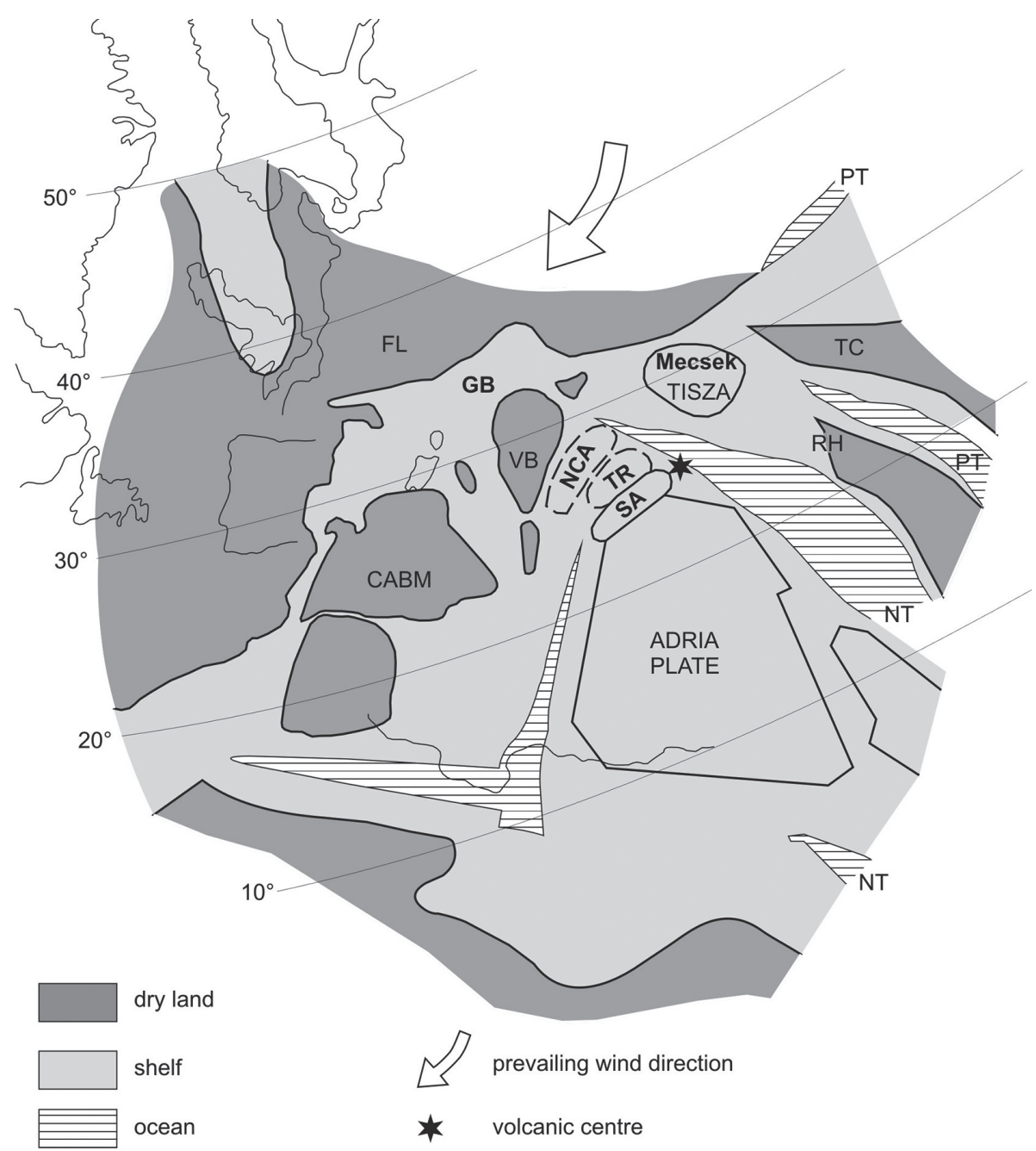

Fig. 2

Paleogeographic map of the western Neotethys during the Middle Triassic (modified after Szulc 2000). Abbreviations: $\mathrm{CABM}=$ Central, Armorican, Brabant and London Massif; FL $=$ Fennoscandian Land; $\mathrm{GB}=$ Germanic Basin; NCA $=$ Northern Calcareous Alps; NT = Neotethys; $\mathrm{PT}=$ Paleotethys; $\mathrm{SA}=$ Southern Alps; RH = Rhodopes; TC = Transcaucasus; TR = Transdanubian Range; VB = VindelicianBohemian Massif 
During the Middle Triassic, complex block movements occurred related to the rifting of the Neo-Tethys (Konrád 1998), reactivating Variscan fault-systems (Szulc 2000). The area of the Mecsek Mountains was also affected by a complex post-Triassic deformation history: at least two Cretaceous and five Tertiary tectonic phases were distinguished (Wein 1967; Némedi-Varga 1983; Bergerat and Csontos 1988; Csontos et al. 2002), which occurred in response to regional tectonics related to the structural evolution of the Alpine-Carpathian system. These processes are reflected in the complex structural architecture of the Mecsek Mountains.

\section{Stratigraphic framework}

The currently accepted stratigraphic subdivision of the Triassic to Lower Jurassic succession of the Mecsek Mountains is presented in Fig. 3. The succession clearly shows the Germanic-type tripartite stratigraphic structure with coarse-grained siliciclastics in the Lower and Upper Triassic and shallow marine carbonates in the Middle Triassic ("Muschelkalk").

The Lower Anisian succession is characterized by fine-grained shallow marine siliciclastics (Patacs Siltstone Formation) and a carbonate-evaporite sequence (Hetvehely Dolomite Formation). Upward-deepening carbonate ramp deposits were formed during the Middle Anisian (Viganvár Limestone, Rókahegy Dolomite, Lapis Limestone and Zuhánya Limestone Formations). Sea-level fall in the Late Anisian led to the deposition of a shallowing-upward succession (Konrád 1998). Due to tectonic processes and sea-level fall various coeval shallow-marine environments came into being, providing sites for deposition of the Kán Dolomite Member and the Kozár Limestone Member of the Csukma Formation, and the "Mánfa Siderite" (Mánfa Beds), the Kisrét Limestone Member and the Kantavár Formation (Konrád 1998).

The Kán Dolomite shows sedimentary features (e.g. tepee structures and pseudomorphs after evaporates) suggesting a peritidal depositional environment and an arid climate (Konrád 1997). The Kozár Limestone was formed in an ooid shoal environment. The oncoidal packstone of the Kisrét Limestone was deposited on the more protected landward belt of the oolite shoals (Török 1998).

The organic matter-rich calcareous marl and limestone of the Kantavár Formation were deposited in a brackish lagoon, under dysaerobic conditions (Monostori 1996; Török 1998). According to Wein (1961) alternating siltstone, sandstone and claystone ironstone occur in the upper part of the Kantavár Formation, representing the transition into the Upper Triassic Karolinavölgy Sandstone Formation.

The fluvial-deltaic and swamp facies of the Karolinavölgy Sandstone Formation was formed during humid climatic periods in the Carnian and Rhaetian (Török 1993; Bóna 1995; Viczián 1995; Haas et al. 2012). Sedimentation was interrupted during the Norian, probably due to an arid climate (Haas et al. 2002), and resumed during the Rhaetian (Bóna 1995). Sideritic claystone ironstone is common in the upper (Rhaetian) part of the Karolinavölgy Sandstone Formation. These claystone 


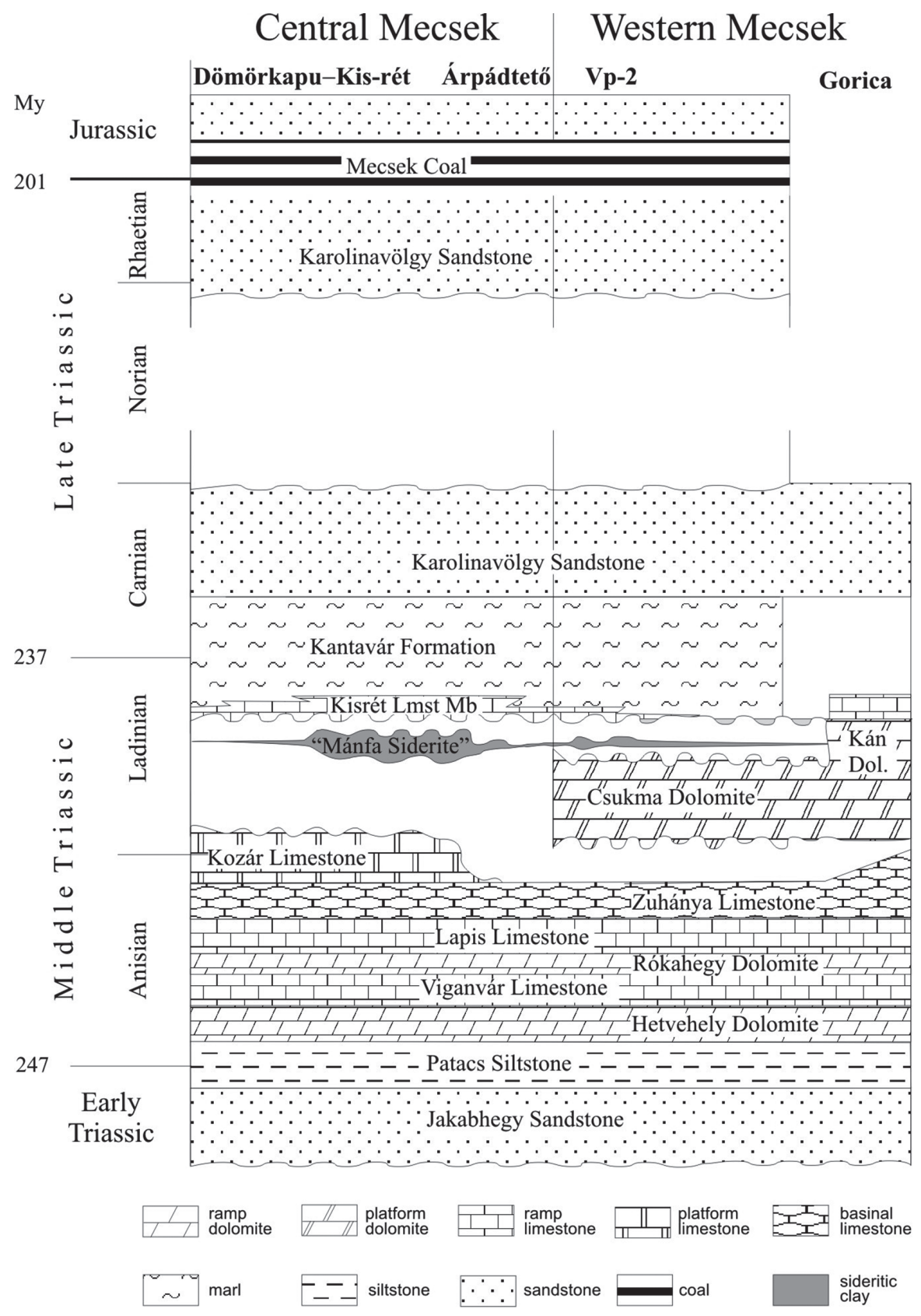

Fig. 3

Chronostratigraphic chart of the Triassic and lowermost Jurassic lithostratigraphic units of the Mecsek Mts. (after Budai and Konrád 2012) 
ironstone layers were formed in a lagoonal and lacustrine environment, according to Nagy et al. (2008).

The lower and middle parts of the Mecsek Coal Formation (Upper Triassic-Lower Jurassic) contain numerous siltstone and sandstone beds with significant siderite content (Némedi-Varga 1995; Nagy et al. 2008). The middle part of the formation is characterized by the presence of volcanic tuff layers of variable thickness and thin coal seams interbedded with the siderite-bearing clastics (Némedi-Varga 1995). Based on petrological analysis of these tuff layers an acidic volcanic source was inferred (Némedi-Varga 1995, and references therein).

\section{Occurrences of the "Mánfa Siderite" and the green clays}

\section{"Mánfa Siderite"}

The "Mánfa Siderite" was reported from three boreholes in the central part of the Mecsek Mountains (Komló K-71, Komló K-72, and Kantavár-1; Fig. 4). Publications dealing with these successions (Nagy 1978; Nagy and Hámor 1979) were based on the original study by Nagy and Ravasz-Baranyai (1968). Clayey beds of the "Mánfa Siderite" were also reported from Árpádtető and Dömörkapu (Hervai 2006).

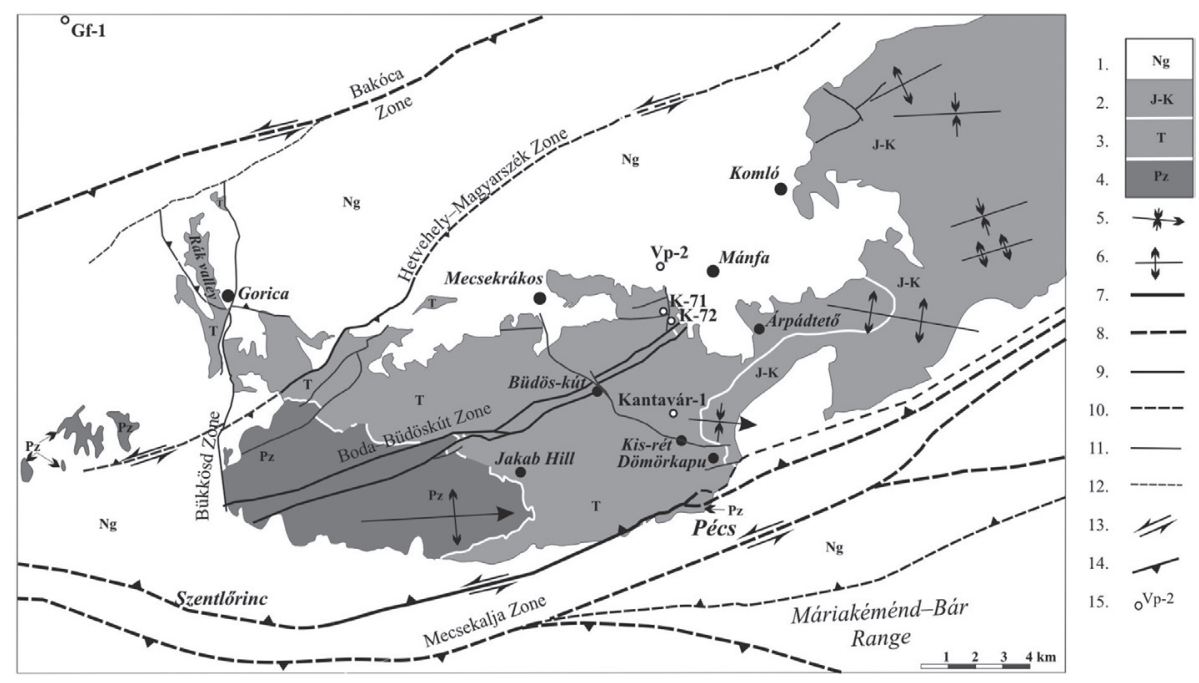

Fig. 4

Simplified tectonic map of the Western and Central Mecsek Mts. showing the location of the outcrops and boreholes discussed in the text (after Konrád and Sebe 2010). Legend: 1. Neogene formations; 2. JurassicCretaceous formations; 3. Triassic formations; 4. Paleozoic formations; 5. syncline axis; 6 . anticline axis; 7. first-order tectonic element; 8. interpreted first-order tectonic element; 9. measured second-order tectonic element; 10. interpreted second-order tectonic element; 11. measured third-order tectonic element; 12. interpreted third-order tectonic element; 13 . strike-slip fault; 14. overthrust; 15 . borehole 
Komló-72

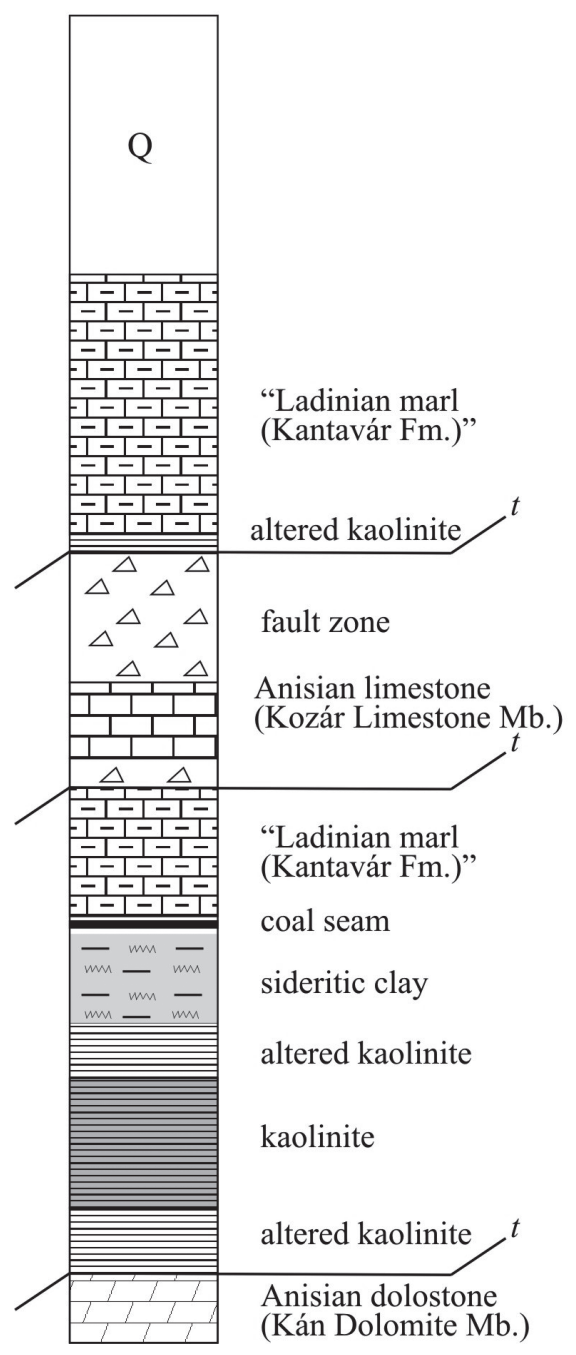

Kantavár-1

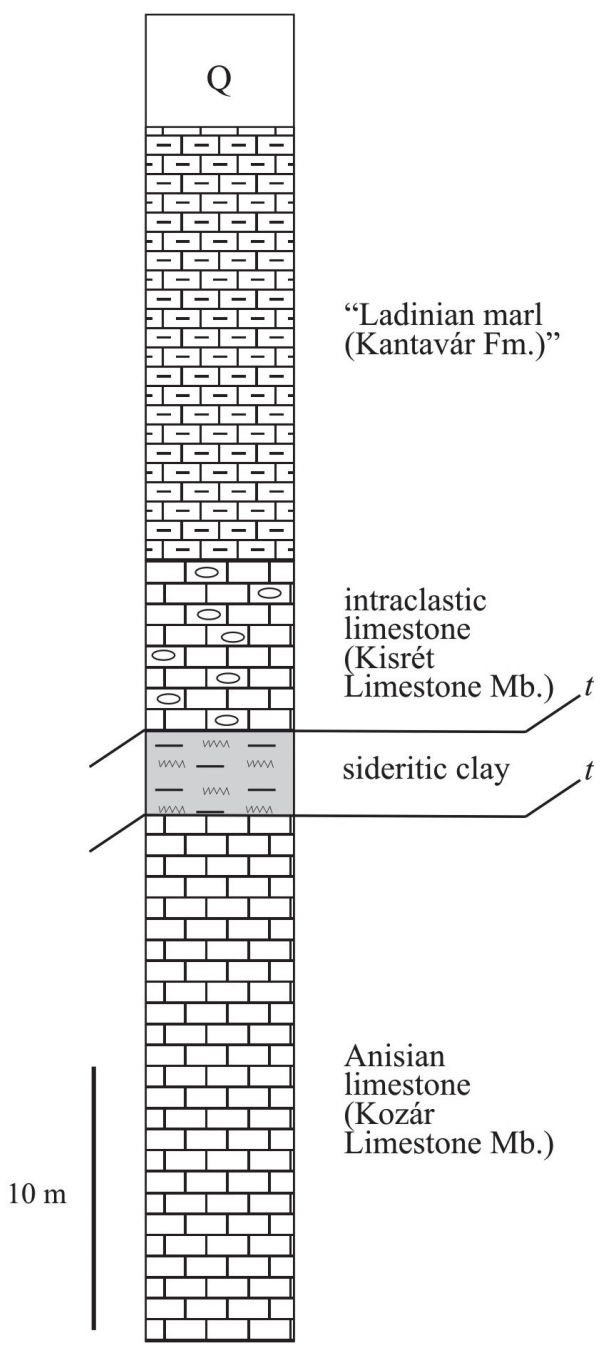

Fig. 5

Lithologic column of the Komló-72 and Kantavár-1 boreholes (modified after Nagy and Ravasz-Baranyai 1968). Abbreviations: $Q=$ Quaternary; $t=$ tectonic contact. Quotation marks indicate ambiguous stratigraphic classification

According to Nagy and Ravasz-Baranyai (1968) the succession in the Komló-71 borehole is tectonically highly disturbed. A 6 m-thick limonitic kaolinite bed was revealed above "secondary dolomites". The kaolinite bed is overlain by grey, ostracod-bearing calcareous marl. Nagy and Hámor (1979) described the interval be- 
tween $33.8-36.0 \mathrm{~m}$ in the Komló-71 borehole as "volcanics" and gave the following description, noting that these "volcanics" were not known elsewhere in the Mecsek Mts.: "The rock is unbedded, pinkish yellow and has a silky luster; it is soft and can be scratched by fingernail. It contains many brown limonite spheres of a few $\mathrm{mm}$ diameter. X-ray diffractograms show only kaolinite and quartz."

Nagy and Ravasz-Baranyai (1968) published the lithological log of the Komló-72 borehole (Fig. 5). Siderite, altered kaolinite, unaltered kaolinite and again altered kaolinite beds are situated above the "Anisian dolomite" and below the "Ladinian coal-bearing marl" in the ca. 35-48 m depth interval. A thin kaolinite bed is marked at ca. $20 \mathrm{~m}$ depth above fault breccias and below the "Ladinian marl". A sideritic kaolinite bed from 41-42 m depth was sampled for micro-mineralogical analysis by Nagy and Ravasz-Baranyai (1968).

The lithological log of the Kantavár-1 borehole was also published by Nagy and Ravasz-Baranyai (1968) (Fig. 5). They found a "siderite bed" between a strongly stylolitic "Anisian limestone" bed and an intraclastic limestone, and sampled it for micro-mineralogical analysis in the $26-30 \mathrm{~m}$ depth interval.

Hervai (2006) described a $10 \mathrm{~cm}$-thick, yellowish clayey bed underlying the oncoidal Kisrét Limestone and overlying the "strongly dolomitized Zuhánya Lime-

\section{Dömörkapu-Kis-rét}
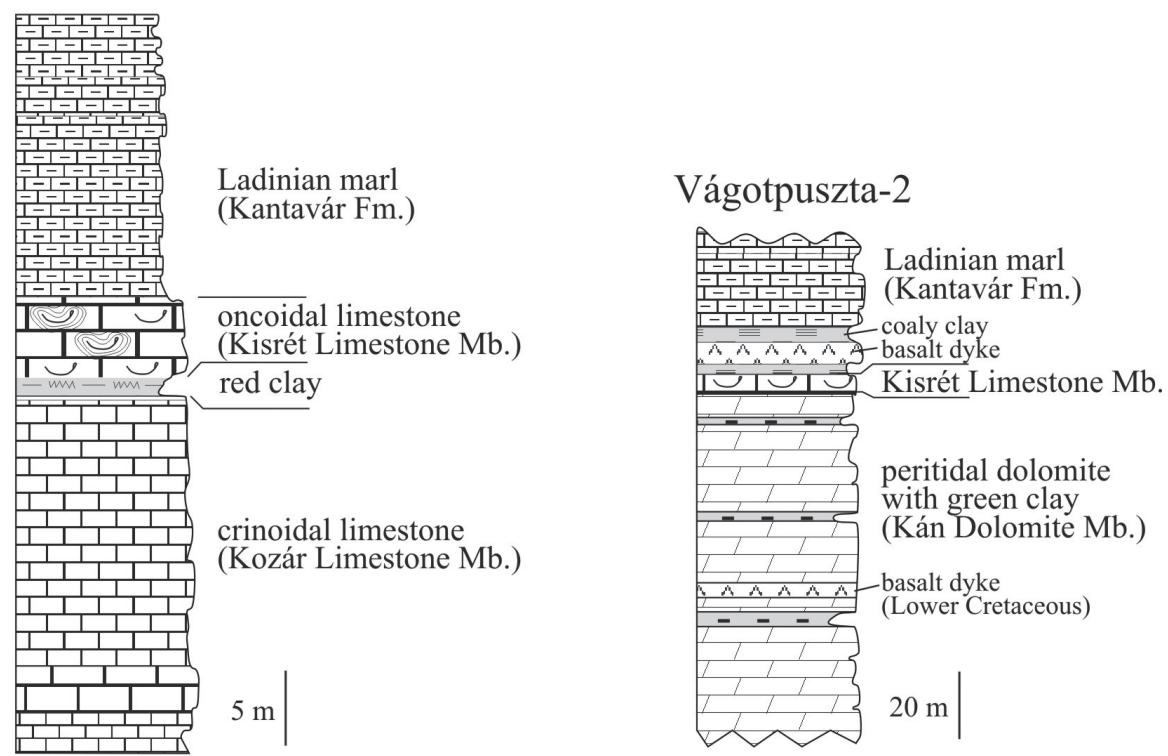

Fig. 6

Lithologic column of the Dömörkapu-Kis-rét type-section and the Vágotpuszta-2 (Vp-2) borehole (modified after Konrád 1997, and Konrád and Budai 2009, respectively) 
stone" at Árpádtető (Central Mecsek, Fig. 4), as well as a "sideritic, brownish-red, 5-10 cm-thick layer" and a yellowish-white clay layer at the type location of the oncoidal Kisrét Limestone along the trail connecting Dömörkapu and Kis-rét (Fig. 4) overlying the Kozár Limestone and underlying the oncoidal Kisrét Limestone (Fig. 6).

\section{Green clay layers}

Green clay intercalations in Middle Triassic (Late Anisian) dolostone near Gorica in the Gorica Valley (= Rák Valley, Western Mecsek Mountains) (Fig. 4) were first documented by Wéber (1965). He found green clay layers in the upper part of the ochre dolostone (Kán Dolomite) mostly occurring in 1-4 cm strings, with a maximum thickness of $15 \mathrm{~cm}$. These grayish green carbonaceous clay layers are parallel to the bedding, have an uneven, slightly undulating surface and contain thin bands and fragments of the host dolostone.

Sixteen green clay layers were documented by Wéber (1978) intercalated into and overlying the Anisian dolostone (Kán Dolomite) in the interval between 61.9 and $150.0 \mathrm{~m}$ in the Vágotpuszta Vp-2 borehole (Figs 4, 6). According to the observations of Wéber (1978) the yellowish green, green, light grey, 2-15 cm-thick clay layers have uneven boundaries toward both the underlying and the overlying dolostone beds.

The Gálosfa Gf-1 borehole (Fig. 4) cored the Anisian-Ladinian dolostone (Kán Dolomite) in $\sim 300 \mathrm{~m}$ thickness. In this core the dolostone has a greenish-pinkish tint and thin green clayey layers commonly occur in the entire thickness.

\section{Mineralogical characteristics of the "Mánfa Siderite" and the green clay layers}

Results of X-ray diffractometric (XRD) analysis of the Mánfa Beds were presented in the paper of Nagy and Ravasz-Baranyai (1968), although rather vaguely. Their analysis showed only kaolinite, siderite and quartz above detection limit. The amount of quartz was always less than that of the kaolinite and the siderite. Where siderite was the dominant constituent there was always some kaolinite, whereas siderite-free kaolinite was also found in the Komló-72 borehole in $5 \mathrm{~m}$ thickness. In the Komló-72 borehole some pyrite and chalcopyrite were detected as well; however, it is not mentioned whether they occurred in the sideritic or in the siderite-free clay samples. Siderite of the Mánfa Beds occurs as encrustations on mineral grains $(0.06-0.3 \mathrm{~mm}$ grain size) and of spheroidal and massive habit (Nagy and Ravasz-Baranyai 1968).

Nagy and Ravasz-Baranyai (1968) distinguished three mineral groups based on micro-mineralogical analysis of the sideritic-kaolinitic beds: (1) minerals from terrigenous sediment input (quartz, rutile, inclusion-rich garnet, rounded zircon, 
titanite, epidote, tourmaline, kyanite, tremolite, muscovite), (2) minerals of pyroclastic origin (idiomorphic-hypidiomorphic magnesite, idiomorphic zircon, inclusion-free garnet, very rare biotite, hypersthene, amphibole, very rare volcanic glass), and (3) authigenic minerals (kaolinite, spheroidal or massive siderite, crystalline pyrite and pyrite concretions, zoisite, clinozoisite, alunite, iron-hydroxide, $<0.2 \mathrm{~mm}$ idiomorphic fluorite). The origin of brookite and perovskite was deemed indeterminable.

XRD analysis (Raucsik in Hervai 2006) of the clayey beds at Árpádtető and Dömörkapu revealed that the main constituent of the clayey material at Árpádtetö is calcite. Smectite+illite/smectite mixed-layered clay (I/S), and other $10 \AA$ phases are also significant. Accessory constituents are quartz, goethite, anatase and amorphous material. The clay fraction is almost entirely composed of illite \pm muscovite with some kaolinite and I/S. No siderite was detected by XRD.

The main constituents of the red clay sample collected at Dömörkapu are goethite and quartz (XRD results; Raucsik in Hervai 2006). Another important constituent is smectite $( \pm \mathrm{I} / \mathrm{S})$. Accessory minerals are calcite, hematite, kaolinite, $10 \AA$ clays and amorphous material. The clay fraction is mainly kaolinite with some $10 \AA$ phases and trace amount of I/S. Siderite was not detected.

Wéber (1965) found abundant white calcite, common limonite spheres after pyrite and a few angular detrital quartz grains in the elutriation residue of the green clay layers intercalated into the Middle Triassic dolostone (Kán Dolomite) near Gorica. Differential thermal analysis (DTA) of the clay samples showed the presence of montmorillonite, while XRD also showed halloysite and kaolinite.

Konrád and Budai (2009) collected samples of green clay intercalations from the same location sampled by Wéber (1965). Their XRD analysis showed that the sample is mainly composed of calcite (79\%) and some clay minerals (10\%). The clay mineral composition is mostly illite with some illite-montmorillonite.

Derivatographic analysis (DTA-TG) showed illite-montmorillonite and kaolinite mineralogical composition of a clay sample overlying the dolostone in the Vp-2 borehole (Wéber 1978). XRD analysis showed 5-15\% quartz, and a minor amount of feldspar in addition to the clay minerals. Two more green clay samples were analyzed: a sample from $72 \mathrm{~m}$ with kaolinite as the main clay mineral, minor illite and high dolomite content, and another clay sample from $100 \mathrm{~m}$ with illite as the main clay mineral, some kaolinite, and 30\% calcite.

\section{Materials and methods}

No core material, thin section or any residual rock sample is available anymore for re-examination of the "Mánfa Siderite". Consequently, our analyses had to be restricted to outcrop samples of the greenish-grey clay-bearing layers collected from the Rák Valley near Gorica, and to core samples collected from the Vp-2 borehole (Fig. 4). 

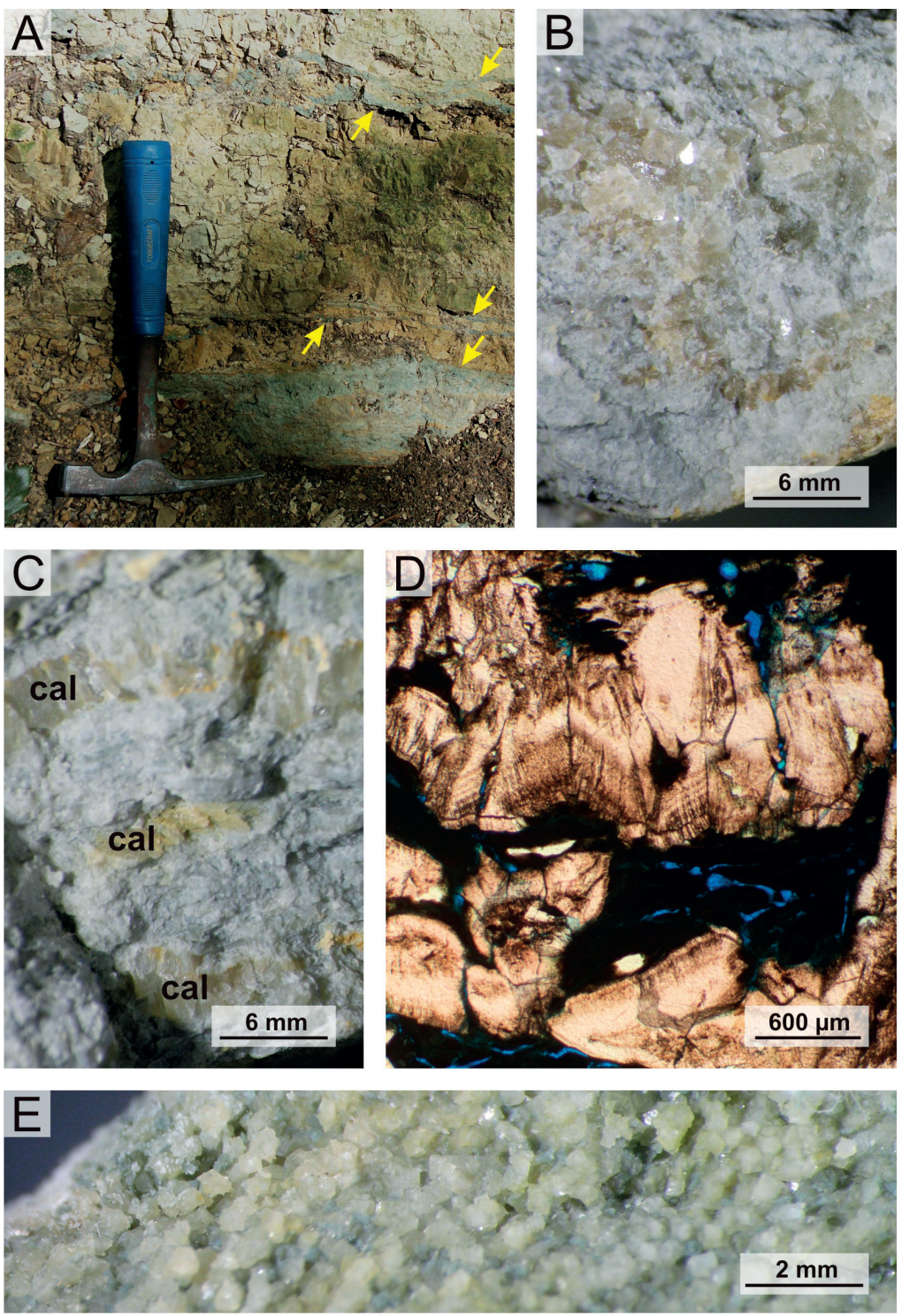

Fig. 7

Characteristics of the green clay-bearing layers. A: Thin light green clayey layers (yellow arrows) interbedded with yellowish-brown dolostone. Hammer for scale (Rák Valley). B: Greenish-grey clay disseminated among light brownish-grey calcite (Rák Valley). C: Calcite veinlets (cal) within the clay layer. Yellowish colors associated with the calcite veinlets indicate the presence of limonite (Rák Valley). D: Microphotograph of the calcite associated with the clays. The solid inclusions in the calcite are arranged in growth zones. The clay minerals form a dark mass impregnated with blue epoxy. Plain polarized light (Rák Valley). E: Light greenish grey clay disseminated among light ochre ferroan dolomite/ankerite crystals $(\mathrm{Vp}-2)$ 
In the Rák Valley light greenish-grey clay-bearing layers are intercalated into a finely crystalline yellowish brown dolostone. The thickness of the greenish, clayey, bedding-parallel layers is ca. 1-2 cm (Fig. 7A); they are mainly composed of light brown or colorless calcite with light greenish-grey clay (Fig. 7B). The relative amount of the clay and the calcite is locally variable within a single layer. The calcite often occurs in veinlets with a thin limonitic lining at the boundary toward the clayrich host (Fig. 7C). The calcite is solid inclusion-rich (Fig. 7D).

In the $\mathrm{Vp}-2$ borehole the greenish-grey clayey beds also contain abundant carbonate minerals with varying amounts of greenish-grey clay among the medium to coarsely crystalline euhedral-subhedral carbonate crystals (Fig. 7E).

The semi-quantitative mineralogical characterization of three samples (two from the Rák Valley, one from Vp-2) was performed at the Institute for Geological and Geochemical Research, Hungarian Academy of Sciences, Research Centre for Astronomy and Earth Sciences with a PHILIPS PW 1710 X-ray diffractometer using a graphite monochromator and $\mathrm{Cu}$ tube. X-rays were generated at $35 \mathrm{~mA}$ and $45 \mathrm{kV}$.

For the investigation of the clay fraction of the samples (grain size $<2 \mu \mathrm{m}$ ) the samples were treated with $10 \%$ acetic acid for carbonate removal and saturated with ethylene-glycol for the determination of the swelling clays. Heat treatments at $350{ }^{\circ} \mathrm{C}$ and $550{ }^{\circ} \mathrm{C}$ were also performed.

\section{Results}

The mineralogical composition of the two samples (samples 45/1 and 45/2) from the Rák Valley is similar: the main mineral is calcite, some dolomite and illite, and minor quartz and feldspar also occur. The composition of the sample from $\mathrm{Vp}-2$ is significantly different from that of the Rák Valley samples. The main mineral in this sample is ankerite. This sample has ca. twice as much clay content as the samples from the Rák Valley. Minor amounts of calcite, quartz and feldspar were also found in this sample.

The only clay mineral in the samples from the Rák Valley is illite with some ( $\sim 5 \%)$ swelling component. A minor amount of feldspar also occurs in the $<2 \mu \mathrm{m}$ fraction. XRD patterns of the clay fraction of 45/1 sample are shown in Fig. 8. In the case of Sample 45/2 a minor amount of smectite layers can be found in the illite. The clay mineral composition of the sample from $\mathrm{Vp}-2$ is somewhat different from the samples from the Rák Valley (Fig. 9). The dominant clay mineral in this sample is also illite; however, beside illite, there is a significant amount of mixed layer illite-smectite (I/S) in the clay fraction, containing a $20-25 \%$ swelling component. Although the $\mathrm{d}_{060}$ values $(1.503 \AA)$ indicate the dioctahedral character of the clay minerals, it should be noted that the color of all three samples changed from greenish to reddish after heating, which suggest the presence of iron in the illite and $\mathrm{I} / \mathrm{S}$. 


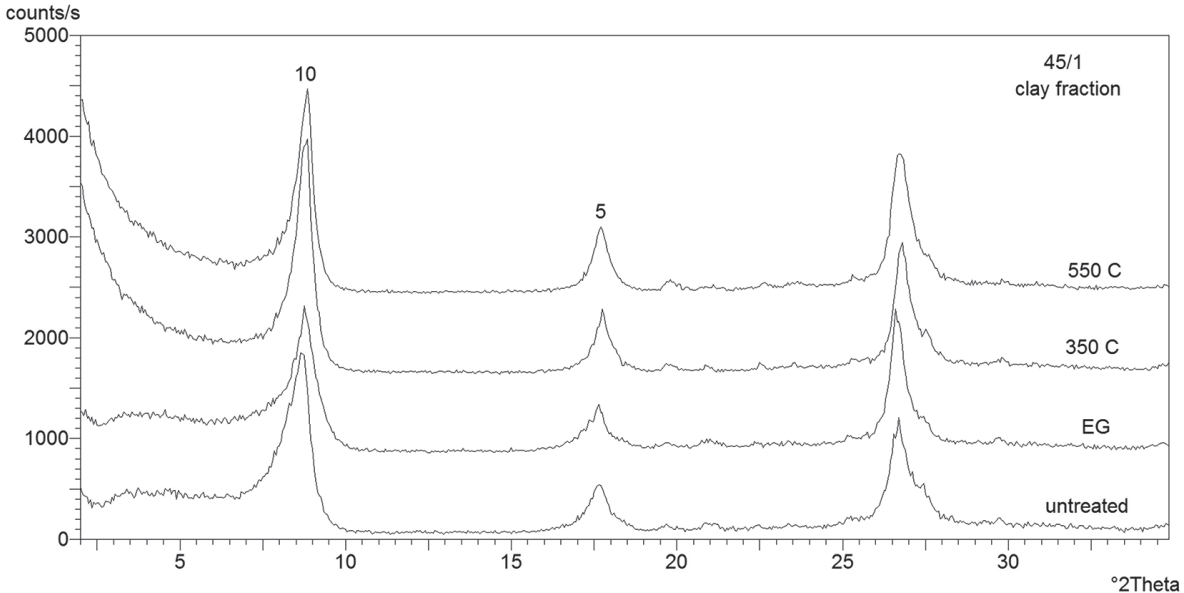

Fig. 8

XRD patterns of the clay fraction of the 45/1 sample from the Rák Valley. Numbers indicated spacings in $\AA . \mathrm{EG}=$ ethylene glycol solvated, $350 \mathrm{C}$ and $550 \mathrm{C}=$ heat treatment at $350{ }^{\circ} \mathrm{C}$ and $550{ }^{\circ} \mathrm{C}$

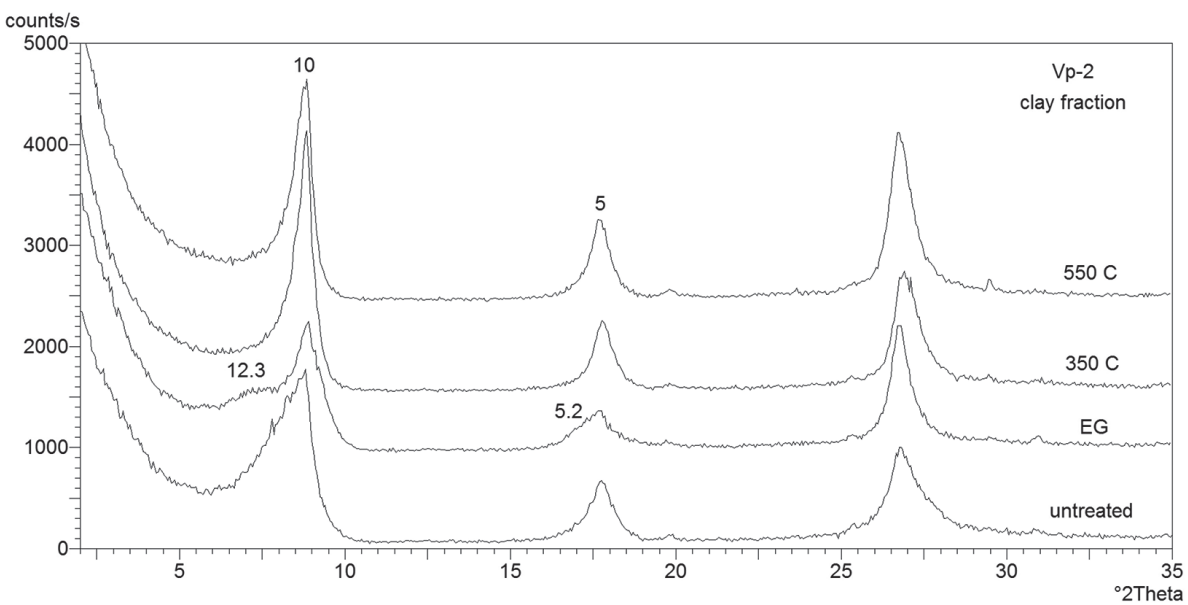

Fig. 9

XRD patterns of the clay fraction of the Vp-2 sample. Numbers indicated spacings in $\AA$. EG = ethylene glycol solvated, $350 \mathrm{C}$ and $550 \mathrm{C}=$ heat treatment at $350{ }^{\circ} \mathrm{C}$ and $550{ }^{\circ} \mathrm{C}$ 


\section{Discussion}

\section{Origin of the "Mánfa Siderite"}

Based on the micro-mineralogical composition of the sideritic-kaolinitic beds ("Mánfa Siderite") Nagy and Ravasz-Baranyai (1968) interpreted a shallow marine depositional environment with sediment transport from a magmatic and metamorphic hinterland (and/or sedimentary provenance containing redeposited minerals of magmatic and metamorphic sources) with simultaneous deposition of significant amount of pyroclastic material, based on the observation that the minerals interpreted to be of pyroclastic origin are enriched in the $0.06-0.1 \mathrm{~mm}$ grain-size fraction. A distant source and aerial transport of the volcanic material was thus assumed (Nagy and Ravasz-Baranyai 1968).

Nagy and Ravasz-Baranyai (1968) inferred authigenic formation of kaolinite, siderite and pyrite as a result of weathering of the terrigenous material in an organic matter-rich, acidic environment. This is in accordance with the generally accepted interpretation of early diagenetic siderite formation. Such conditions can be found in freshwater swamp environments with a tropical climate and lush vegetation (Curtis and Coleman 1986). According to the siderite formation model of Curtis and Coleman (1986) the iron is sourced from the weathering of lateritic soils. This fine-grained sediment is buried along with organic matter. Below the sediment/water interface organic degradation results in microbial methanogenesis, iron oxide reduction, and supersaturation with respect to siderite. In this setting siderite is formed according to the following reaction (Curtis and Coleman 1986):

$$
7 \mathrm{CH}_{2} \mathrm{O}+2 \mathrm{Fe}_{2} \mathrm{O}_{3} \rightarrow 3 \mathrm{CH}_{4}+4 \mathrm{FeCO}_{3}+\mathrm{H}_{2} \mathrm{O}
$$

The presence of kaolinite associated with the siderite supports the theory that the iron for the siderite was sourced from the weathering of lateritic soils under humid tropical-subtropical climatic conditions. In freshwater environments sulfate activity is very low; therefore, iron will not be incorporated into iron sulfides, as opposed to under normal marine conditions, where reduced iron would be used up during sulfate reduction to form iron sulfides (pyrite); thus iron is not available to form siderite in marine environments (Young 1989).

Coal beds are commonly underlain by argillaceous layers ("underclay"). The composition of "underclays" ranges from mixtures of illite, mixed-layer clay, and kaolinite to pure kaolinite (Huddle and Patterson 1961). Several theories exist regarding the origin of "underclay" layers. They are most probably alteration products, either of the sediment underlying the coal or a paleosol horizon formed prior to the development of the coal-forming vegetation (see Rimmer and Eberl 1982, and references therein). Consequently, the composition of the "underclay" is a result of post-depositional alteration; therefore its mineralogical composition no longer reflects that of the source area of the sediment. It is not clear, however, whether the alteration of the underlying 
sediment took place during soil formation, or beneath the swamp, or during burial, or as a result of a multiphase process encompassing all three above-described processes (Rimmer and Eberl 1982).

In the Komló-72 borehole siderite-bearing kaolinite beds were documented underlying an organic matter-rich marl with a thin coal seam (Fig. 5). Thus it can be assumed that the succession was deposited in a swamp environment similar to that presented above, rather than in a shallow marine environment as suggested by Nagy and Ravasz-Baranyai (1968). However, it is also possible that the original sediment was deposited in a shallow marine environment and later altered to "underclay" in a swamp environment via processes similar to those proposed by Huddle and Patterson (1961). Some volcanic material might have been incorporated into these sediments. By and large these considerations are in agreement with the inferences of Nagy and Ravasz-Baranyai (1968).

Since the clayey layers studied by Hervai (2006) have significantly different mineralogical composition compared to that of the "Mánfa Siderite" beds studied by Nagy and Ravasz-Baranyai (1968) we consider his correlation of these clayey layers with the sideritic-kaolinitic beds occurring near Mánfa unsubstantiated.

\section{Stratigraphic position of the "Mánfa Siderite"}

In the strongly tectonized Central Mecsek Mountains, the "Mánfa Siderite" was identified in structurally highly disturbed boreholes (Fig. 5) in the vicinity of major structural elements (Fig. 4), such as the Boda-Büdöskút Zone and other first-order structural elements (see Konrád and Sebe 2010). Its chronostratigraphic assignment was based on the fossil content of the underlying formation, micro-mineralogical considerations, and the assumed analogy with Middle Triassic volcanic layers of Alpine areas (Nagy and Ravasz-Baranyai 1968). According to the currently accepted stratigraphic subdivision of the Triassic of the Mecsek Mountains the "Mánfa Siderite" is placed at the basal part of the Kantavár Formation (below the Kisrét Limestone Member) following and preceding a hiatus (Fig. 3). This assignment is based on the observation that the "Mánfa Siderite" was found above Anisian carbonates. An erosional contact was described by Nagy and Ravasz-Baranyai (1968); however, a tectonic contact seems to be more realistic in the highly disturbed succession of the studied boreholes. Since reassessing of the cores is not possible anymore, any further inferences are purely speculative.

According to Wein (1961) claystone ironstone occurs in the upper part of the Kantavár Formation, alternating with siltstone and sandstone, as well as in the upper part of the Upper Triassic Karolinavölgy Sandstone Formation (Nagy et al. 2008). Siderite is also common in the Upper Triassic-Lower Jurassic coal-bearing succession (Mecsek Coal Formation), especially in the geochemically distinct Rhaetian sideritic unit, which was used as a marker horizon for the correlation of the coal-seams (Némedi-Varga 1995, and references therein). Volcanic tuffite layers are also characteristic of the Mecsek Coal Formation (Némedi-Varga 1995). Lower Jurassic black 
argillaceous deposits with sideritic concretions and greenish cinerites also occur in the Codru Nappe System of the Tisza Mega-Unit (Vaşcău Nappe, Codru-Moma Mts., Romania) (Haas et al. 2010b). Therefore sideritic-tuffitic layers are not uncommon in the Lower Jurassic successions of the Tisza Mega-Unit. Accordingly, it seems probable that the sideritic-kaolinitic layers penetrated by the boreholes studied by Nagy and Ravasz-Baranyai (1968) (Fig. 5) are actually tectonically displaced fragments of a younger siderite-bearing formation. This hypothesis is supported by the common occurrence of volcanic layers within the Lower Jurassic succession; whereas, according to the most recent paleogeographic reconstructions (e.g. Feist-Burkhardt et al. 2008), no volcanic source was close enough to the study area during the Middle Triassic to provide sufficient material to form tuffite layers. Furthermore, the direction of the trade winds during the Middle Triassic (Fig. 2) does not support the hypothesis that pyroclastic material was carried to the site of deposition from the same source as for the Middle Triassic pyroclastics found elsewhere (Transdanubian Range, Bükk Mountains, Southern Alps) as suggested by Nagy and Ravasz-Baranyai (1968).

Taking all the above considerations together, we assume that the "Mánfa Siderite" does not represent a unique formation at the base of the Kantavár Formation, but may rather be a tectonically displaced segment of the Mecsek Coal Formation. The "Mánfa Siderite", as defined, was revealed exclusively by boreholes in a strongly tectonized zone near Mánfa. Due to the loss of the old core material it is not possible to re-evaluate either the origin or the stratigraphic position of these clayey beds. Based on the above discussion and the ambiguity surrounding the Mánfa Beds, we suggest the removal of this unit from the lithostratigraphic division.

\section{Origin of the green clay layers}

The green clay intercalations in the dolostone (Kán Dolomite) in the Rák Valley near Gorica and in the Vp-2 borehole were considered to be of volcanic origin mostly based on the analogy with other Middle Triassic carbonates containing green clay intercalations (Wéber 1965, 1978). Green volcaniclastic horizons ("pietra verde") related to the intense volcanism near the Anisian-Ladinian boundary in the Tethyan region are known from numerous locations in the Alps (e.g. Bosellini 1991; Krainer and Lutz 1995), Apennines (e.g. Martini et al. 1986), Carpathians (e.g. Koszowska et al. 1998; Olašavský 2001), and also in the Transdanubian Range in Hungary (e.g. Budai and Vörös 2006). However, no pyroclastics have been found in the Peri-Tethyan region (Germanic and Silesian Basins) in this time interval, due to the upwind location of this region relative to the volcanic sources (Szulc 2000).

Analytical results of Wéber (1965) showed the presence of halloysite in the samples, which, indeed, primarily occurs as a weathering product of volcanic materials, although it may also form in tropical soils (Wilson 1999). Nevertheless, recent analysis of these green clays (Konrád and Budai 2009, and this study) showed the presence only of illite and I/S clay minerals. Based on the results of the present study, the clay mineralogical composition of the sample from the $\mathrm{Vp}-2$ borehole is similar to that 
of the Rák Valley clays: it is composed of illite with some swelling components; however, Wéber (1978) also reported the presence of kaolinite. In addition to the paleogeographic considerations presented above, with regard to the Middle Triassic volcanic sources the current mineralogy of the clay samples (illite and I/S) does not prove a volcanogenic origin either.

The Kán Dolomite was formed in a peritidal environment under semi-arid to semi-humid climatic conditions (Konrád 1997). Repeated subaerial exposure may have resulted in the formation of paleosols as suggested by Konrád (1997) who described the green clay layers as A members of Lofer cycles in other sections of the same formation. However, no sedimentary features characteristic for pedogenesis (e.g. root casts) have been found in the studied sections in the Rák Valley and the Vp-2 borehole; therefore, a pedogenic origin for these clay intercalations cannot be proved. It is more likely that the clayey material was derived from the terrestrial hinterland; thus it is of detrital origin (cf. Shinn 1983).

Although the presence of illite and smectite may indicate arid climate (Weaver 1989), illite more commonly forms via transformation (illitization) during burial diagenesis. Studies of sandstones showed that the rate and extent of illitization of aluminous clay minerals (e.g. smectite, kaolinite) depend on the supply of K, temperature/ burial depth and time, and that illitization occurs via layer by layer replacement of smectite to yield mixed-layered I/S minerals, and eventually pure illite (e.g. Bjørlykke 1998). Given that the Middle Triassic succession of the Mecsek Mountains may have reached up to ca. $5 \mathrm{~km}$ maximum burial depth by the mid-Cretaceous, as estimated from the maximum thickness of the overlying successions (Haas 2012), and from clay mineral and organic maturation data of Jurassic formations (Raucsik and Varga 2008, and references therein), it is likely that the currently observable mineralogy of the clays intercalated into the dolostone is a result of illitization during burial diagenesis, and does not represent conditions during deposition. Therefore, we assume that the studied clay layers are terrigenous deposits and the current clay mineralogy is a result of diagenetic transformation.

Wéber (1978) correlated the green clay layers intercalated in the Middle Triassic dolostone with the sideritic-kaolinitic layers of the "Mánfa Siderite", inferring the same stratigraphic position and origin for these clays. Based on the compositional differences and the above considerations regarding the proposed stratigraphic position of the Mánfa Beds, the green clay layers and the sideritic-kaolinitic layers are not related either stratigraphically, or genetically.

\section{Conclusions}

Critical re-evaluation of previously published and new data about the Middle Triassic "pyroclastics" led to the following conclusions:

(1) The Mánfa Beds ("Mánfa Siderite") most probably belong to a sideritic and tuffaceous unit of the Upper Triassic-Lower Jurassic Mecsek Coal Forma- 
tion, which was tectonically placed over the Anisian carbonates in the Central Mecsek Mountains. Therefore, the Mánfa Beds do not represent Middle Triassic pyroclastics. The sideritic-kaolinitic layers were formed in a freshwater swamp environment under humid tropical climatic conditions during the Late Triassic-Early Jurassic. Weathering in an organic matter-rich, acidic environment resulted in the formation of "underclays" and siderite, for which the iron supply was probably sourced from the weathering of lateritic soils.

(2) The green clay intercalations of the Middle Triassic peritidal Kán Dolomite are probably terrigenous sediments, rather than pyroclastic deposits or paleosols, based on its upwind location relative to the Middle Triassic volcanic sources, and on the lack of sedimentary features characteristic for paleosols in the studied section. The original mineralogy of the clays may be masked by thermal alteration of the clays due to their deep burial during the Cretaceous; thus, the illite-I/S mineralogy of these clays probably indicates diagenetic illitization.

\section{Acknowledgements}

This study constitutes a part of the PhD-project of GL supported by the 'Developing Competitiveness of Universities in the South Transdanubian Region' (SROP4.2.1.B-10/2/KONV-2010-0002). The authors are indebted to János Haas and the anonymous reviewers whose suggestions greatly improved the quality of the manuscript.

The present scientific contribution is dedicated to the $650^{\text {th }}$ anniversary of the foundation of the University of Pécs, Hungary.

\section{References}

Bergerat, F., L. Csontos 1988: Brittle tectonics and paleo-stress field in the Mecsek and Villány Mts (Hungary): Correlations with the opening mechanism of the Pannonian basin. - Acta Geologica Hungarica, 31, pp. 81-100.

Beudant, F.S. 1822: Voyage mineralogique et geologique en Hongrie, pendant l'année 1818, II. - Verdière, Paris, 614 p.

Bjørlykke, K. 1998: Clay mineral diagenesis in sedimentary basins: a key to the prediction of rock properties. Examples from the North Sea Basin. - Clay Minerals, 33, pp. 15-34.

Bleahu, M., J. Haas, S. Kovács, Cs. Péró, G.H. Mantea, S. Bordea, S. Panin, M. Stefanescu, Gy. Konrád, E. Nagy, E. Rálisch-Felgenhauer, K. Sikić, Á. Török 1994: Triassic facies types, evolution and paleogeographic relations of the Tisza Megaunit. - Acta Geologica Hungarica, 37, pp. 187-234.

Böckh, J. 1881: Adatok a Mecsek hegység és dombvidéke jurakorabeli lerakódásának ismertetéséhez, I. rész: Stratigraphia (Data for understanding the Jurassic sediments of the Mecsek Mountains and the surrounding hills. Part I: Stratigraphy). - Értekezések a természettudományok köréből, Budapest. (in Hungarian)

Bóna, J. 1995: Palynostratigraphy of the Upper Triassic formations in the Mecsek Mts (Southern Hungary). - Acta Geologica Hungarica, 38, pp. 319-354. 
Bosellini, A. 1991: Geology of the Dolomites. An introduction. - Dolomieu Conference on Carbonate Platform and Dolomitization, Ortisei, pp. 3-43.

Budai, T., A. Vörös 2006: Middle Triassic platform and basin evolution of the Southern Bakony Mountains (Transdanubian Range, Hungary). - Rivista Italiana di Paleontolgia e Stratigrafia, 112, pp. 359-371.

Budai, T., Gy. Konrád 2012: Magyarország földtana (Geology of Hungary). - Digi-Book Magyarország Kiadó, ISBN 978-615-5295-55-3 EPUB. (in Hungarian)

Csontos, L., L. Benkovics, F. Bergerat, J-L. Mansy, G. Wórum 2002: Tertiary deformation history from seismic section study and fault analysis in a former European Tethyan margin (the Mecsek-Villány area, SW Hungary). - Tectonophysics, 375, pp. 81-102.

Curtis, C.D., M.L. Coleman 1986: Controls on the precipitation of early diagenetic calcite, dolomite and siderite concretions in complex depositional sequences. - In: Gautier, D.L. (Ed.): Roles of Organic Matter in Sediment Diagenesis, SEPM Special Publication, 38, pp. 23-33.

Feist-Burkhardt, S., A.E. Götz, J. Szulc, R. Borkhataria, M. Geluk, J. Haas, J. Hornung, P. Jordan, O. Kempf, J. Michalik, J. Nawrocki, L. Reinhardt, W. Ricken, H-G. Röhling, T. Rüffer, Á. Török, R. Zühlke 2008: Triassic. - In: McCann, T. (Ed.): The Geology of Central Europe, Volume 2: Mesozoic and Cenozoic, Geological Society of London, pp. 749-821.

Géczy, B. 1973: The origin of the Jurassic faunal provinces and the Mediterranean plate tectonics. Annales Universitatis Scientiarum Budapestinensis de Rolando Eötvös Nominatae Sectio Geologica, 16, pp. 99-114.

Götz, A.E., Á. Török, S. Feist-Burkhardt, Gy. Konrád 2003: Palynofacies patterns of Middle Triassic ramp deposits (Mecsek Mts., S Hungary): A powerful tool for high-resolution sequence stratigraphy. - Mitteilungen Geoaustria, 46, pp. 77-90.

Haas, J. (Ed.) 2012: Geology of Hungary. -Springer-Verlag, Berlin-Heidelberg, 244 p.

Haas, J., T. Budai, K. Hips, Gy. Konrád, Á. Török 2002: Magyarországi triász fáciesterületek szekvenciarétegtani elemzése (Sequence stratigraphy of Triassic facies areas in Hungary). - Földtani Közlöny, 132, pp. 17-43. (in Hungarian)

Haas, J., T. Budai, L. Csontos, L. Fodor, Gy. Konrád 2010a: Pre-Cenozoic geological map of Hungary, 1:500 000. - Hungarian Geological Institute, Budapest.

Haas, J., S. Kovács, S. Karamata, M. Sudar, H.J. Gawlick, E. Grădinaru, J. Mello, M. Polák, Cs. Péró, B. Ogorelec, S. Buser 2010b: Jurassic environments in the Circum-Pannonian Region. - In: Vozár, J., F. Ebner, A. Vozárová, J. Haas, S. Kovács, M. Sudar, M. Bielik, Cs. Péró (Eds): Variscan and Alpine terranes of the Circum-Pannonian Region, Slovak Academy of Sciences, Geological Institute, Bratislava, pp. 157-202.

Haas, J., T. Budai, B. Raucsik 2012: Climatic controls on sedimentary environments in the Triassic of the Transdanubian Range (Western Hungary). - Palaeogeography, Palaeoclimatology, Palaeoecology, 353-355, pp. 31-44.

Hervai, A. 2006: A mecseki onkoidos mészkő és fekü képződményeinek üledékföldtani vizsgálata (Sedimentological and stratigraphic analysis of the oncoidal limestone and its underlying successions in the Mecsek Mountains). - MSc Thesis, University of Pécs, Pécs, 40 p. (in Hungarian)

Huddle, J.W., S.H. Patterson 1961: Origin of Pennsylvanian "underclay" and related seat rocks. Geological Society of America Bulletin, 72, pp. 1643-1660.

Konrád, Gy. 1997: A DK-dunántúli alsó- és középső-triász képződmények szedimentológiai vizsgálatának eredménye (Results of the sedimentological analysis of the Lower and Middle Triassic formations of SW Transdanubia). - PhD Thesis, Hungarian Geological and Geophysical Institute, Budapest, 118 p. (in Hungarian)

Konrád, Gy. 1998: Synsedimentary tectonic events in the Middle Triassic evolution of the SE Transdanubian part of the Tisza Unit. - Acta Geologica Hungarica, 41, pp. 327-341.

Konrád, Gy., T. Budai 2009: A nyugat-mecseki középső-triász kifejlődési sajátosságai (Characteristics of the Middle Triassic sequence of the western Mecsek Mts). - Földtani Közlöny, 139/2, pp. 119-130. (in Hungarian) 
Konrád, Gy., K. Sebe 2010: Fiatal tektonikai jelenségek új észlelései a Nyugati-Mecsekben és környezetében (New details of young tectonic phenomena in the Western Mecsek Mts. and their surroundings). - Földtani Közlöny, 140/2, pp. 135-162. (in Hungarian)

Koszowska, E., A. Wolska, J. Szulc 1998: Tuffaceous intercalations within the Middle Triassic carbonates of the Hronicum unit in the Western Tatra Mts., Poland. - CBGA XVI Congress, Vienna, Abstracts, p. 290.

Kozur, H., R. Mock 1987: Remarks to the occurrence of "Germanic Triassic" in the Mecsek Mts. (Southern Hungary) and to the relations between the Germanic and Carpathian Keuper. - Mineralia Slovaca, 19, pp. 481-497.

Krainer, K., D. Lutz 1995: Middle Triassic basin evolution and stratigraphy in the Carnic Alps (Austria). - Facies, 33, pp. 167-184.

Martini, I.P., A. Rau, M. Tongiorgi 1986: Syntectonic sedimentation in a Middle Triassic rift, Northern Apennines, Italy. - Sedimentary Geology, 47, pp. 191-219.

Monostori, M. 1996: Ostracods and charophytes from the Triassic Kantavár Formation, Mecsek Mts., Hungary. - Acta Geologica Hungarica, 39, pp. 311-317.

Nagy, E. 1968: Triasbildungen des Mecsek-Gebirges. - Annals of the Hungarian Geological Institute, 51,198 p.

Nagy, E. 1978: Sidérite de Mánfa. - In: Fülöp, J. (Ed.): Lexique Stratigraphique International, Volume I: Europe, Fascicule 9: Hongrie, Centre de la Recherche Scientifique, Paris, pp. 310-311.

Nagy, E., G. Hámor 1979: Mánfa. Magyarázó a Mecsek hegység Földtani Térképsorozatához, 1:10.000es sorozat (Mánfa. Explanation for the 1:10 000 geological map series of the Mecsek Mountains). Hungarian Geological Institute, Budapest, p. 30. (in Hungarian)

Nagy, E., L. Ravasz-Baranyai 1968: Tufás koalinit- és sziderit-telepek a mecseki ladini összlet alján (Tuffitic kaolinite and siderite layers in the base of the Ladinian succession of the Mecsek Mts.). Földtani Közlöny, 98/2, pp. 213-217. (in Hungarian)

Nagy, E., G. Bagoly-Árgyelán, E. Rálisch-Felgenhauer, Á. Siegl-Farkas 2008: A Mecsek hegység felsőtriász képződményei (Upper Triassic formations of the Mecsek Mountains). - Annual Report of the Hungarian Geological Institute, 2008, Budapest, pp. 1-17. (in Hungarian)

Némedi-Varga, Z. 1983: A Mecsek hegység szerkezetalakulása az alpi hegységképzö ciklusban (Tectonics of the Mecsek Mountains in the Alpine orogenic cycle). - Annual Report of the Hungarian Geological Institute, 1981, Budapest, pp. 467-484. (in Hungarian)

Némedi-Varga, Z. (Ed.) 1995: A mecseki feketekőszén kutatása és bányaföldtana (Research and mining geology of the black-coal deposit in the Mecsek Mountains). - University of Miskolc, Miskolc, 472 p. (in Hungarian)

Olašavský, M. 2001: Evidence of volcanism in the Middle Triassic Reifling Limestones of the Hronikum Unit. - Geolines, 13, pp. 97-98.

Peters, K.F. 1862: Über den Lias von Fünfkirchen. Kaiserliche Akademie der Wissenschaften in Wien. - Mathematisch-Naturwissenschaftliche, Klasse Bd., 46, pp. 241-293.

Raucsik, B., A. Varga 2008: Climato-environmental controls on clay mineralogy of the HettnangianBajocian successions of the Mecsek Mountains, Hungary: An evidence for extreme continental weathering during the early Toarcian oceanic anoxic event. - Palaeogeography, Palaeoclimatology, Palaeoecology, 265, pp. 1-13.

Rimmer, S.M., D.D. Eberl 1982: Origin of an "underclay" as revealed by vertical variations in mineralogy and chemistry. - Clays and Clay Minerals, 30, pp. 422-430.

Shinn, E.A. 1983: Tidal flat environment. - In: Scholle, P.A., D.G. Bebout, C.H. Moore (Eds): Carbonate depositional environments. AAPG Memoir, 33, pp. 171-210.

Szulc, J. 2000: Middle Triassic evolution of the northern Peri-Tethys area as influenced by early opening of the Tethys Ocean. - Annales Societatis Geologorum Poloniae, 70, pp. 1-48.

Török, Á. 1993: Storm influenced sedimentation in the Hungarian Muschelkalk. - In: Hagdorn, H., A. Seilacher (Eds): Muschelkalk Schöntaler Symposium, 1991, Goldschneck-Verlag, Stuttgart, pp. $133-142$ 
Török, Á. 1998: Controls on development of Mid-Triassic ramps: examples from southern Hungary. - In: Wright, V.P., T.P. Burchette (Eds): Carbonate Ramps. Geological Society, London, Special Publication, 149, pp. 339-367.

Török, Á. 2000: Muschelkalk carbonates in southern Hungary: An overview and comparison to German Muschelkalk. - Zentralblatt für Geologie und Paläontologie, I, 9/10, pp. 1085-1103.

Vadász, E. 1935: Das Mecsek-Gebirge. - Hungarian Geological Institute, Budapest, 180 p.

Viczián, I. 1995: Clay minerals in Mesozoic and Paleogene sedimentary rocks of Hungary. - Romanian Journal of Mineralogy, 77, pp. 35-44.

Weaver, C.E. 1989: Clays, Muds, and Shales. - Developments in Sedimentology, 44, Elsevier, Amsterdam, New York, 819 p.

Wéber, B. 1965: Zöldagyag-betelepülés nyugat-mecseki felsőanizusi dolomitösszletből (GrüntonLagen im oberanisischen Dolomitkomplex des W-Mecsek). - Földtani Közlöny, 95/4, pp. 47-53. (in Hungarian)

Wéber, B. 1978: Újabb adatok a Mecsek-hegységi anizuszi és ladini rétegek ismeretéhez (Neuer Beitrag zur Kenntnis der anisischen und ladinischen Schichten des Mecsek-Gebirges). - Földtani Közlöny, 108/2, pp. 137-148. (in Hungarian)

Wein, Gy. 1961: Szerkezetalakulás mozzanatai és jellege a Keleti-Mecsekben (Stages and characteristics of the structural evolution of the Eastern Mecsek Mountains). - Annals of the Hungarian Geological Institute, Budapest, 49, 759 p. (in Hungarian)

Wein, Gy. 1967: Délkelet-Dunántúl hegységszerkezete (Über die Tektonik Südost-Transdanubiens). Földtani Közlöny, 97/4, pp. 371-395. (in Hungarian)

Wilson, M.J. 1999: The origin and formation of clay minerals in soils: past, present and future perspectives. - Clay Minerals, 34, pp. 7-25.

Young, T.P. 1989: Phanerozoic ironstones: An introduction and review. - Geological Society, London, Special Publications, 46, pp. ix-Xxv. 